\title{
METABOLISM OF CONNECTIVE TISSUE IN LIMB ATROPHY IN THE RABBIT
}

BY

\author{
JAMES W. BROOKE* AND H. G. BEWICK SLACK \\ From the Rheumatism Research Centre, University of Manchester
}

In previous experiments in adult rats (Slack, 1954, 1955), massive tissue atrophy was induced by denervation and femoral head dislocation of one hind limb. A study of the metabolism of total collagen, total sulphated polysaccharide, and mixed muscle protein indicated that disuse atrophy does not imply cessation of all protein or polysaccharide synthesis. After the onset of atrophy some synthesis of collagen appears to continue for at least 15 weeks. Synthesis of muscle protein continues for about 6 weeks and of sulphated polysaccharide for at least 2 weeks. The interesting finding was that at least some of the normal synthetic processes continue despite massive removal of muscle protein and connective tissue.

These earlier experiments did not differentiate between connective tissue closely associated with the muscle mass, and connective tissue in the bones, joints, and associated tendon insertions. Furthermore, the rat experiments were open to objection because of the unusual operative technique required to achieve aseptic atrophy, and the fact that the bones of the rat appear to be capable of growth throughout much of the life of the animal. In view of the unexpected finding of continued connective tissue synthesis in the atrophying rat limb it was considered desirable to repeat the experiments in a larger animal.

In the present experimental work, to be described, atrophy has been induced in one hind limb of rabbits by denervation. The metabolism of connective tissue collagen fractions and sulphated polysaccharide has been studied in two limb components: connective tissue associated with the muscle mass (soft tissue compartment), and that in bones, joints, and tendon insertions (skeletal compartment).

Both the present work, and the previous experi-

\footnotetext{
*n leave from the Eugene Hospital and Clinic, Oregon, U.S.A.
}

ments in rats, are concerned with disuse atrophy. Gillespie (1954) showed that, in a paralysed limb. the main factor in atrophy is, in fact, disuse. Diminution of blood supply is not a controlling factor. It also appears from his work that the bony changes in the paralysed limbs are due to quantitative differences, and not to alterations in quality of the bones-as judged by breaking stress, elasticity, percentage of ash, and specific gravity. $X$ rays show a loss of density in disused limb bones, described as decalcification or osteoporosis. Gillespie's work shows that these terms may be misleading.

More recently Geiser and Trueta (1958) have described changes in the calcaneum of the rabbit, atrophying as the result of tendo calcaneus section, plaster immobilization, and other means. Bone removal was found to occur up to 5 or 6 weeks after the onset of atrophy. Thereafter there appeared to be little further bone removal. This timeinterval corresponds to the time required for complete muscle atrophy and cessation of muscle protein synthesis in the rat experiments quoted above (Slack, 1954). It is interesting that Geiser and Trueta, in their experiments, found evidence of osteoblasts at all stages of atrophy. In other words, some synthesis of new connective tissue must be occurring in the bone despite overall atrophy. This finding is in agreement with the experiments on collagen metabolism in atrophying rat limbs quoted earlier.

A considerable volume of work has been published on changes in muscle proteins following denervation, tenotomy, and plaster fixation. The interested reader is referred to Helander (1957) for an excellent review and results of original work. The impact of atrophy on the connective tissues appears still to be receiving less attention than it deserves. It is hoped that the experiments to be described will, in some measure, add to our knowledge of connective tissue behaviour in massive tissue atrophy. 


\section{Experimental Methods}

\section{Operative Procedure}

Young adult rabbits weighing 1.8 to $2 \mathrm{~kg}$. were subjected to neurectomy under ether anaesthesia and local nerve blocks. In each case an attempt was made to transect, and remove at least a distal one inch of, all motor nerves to the left hind limb. The approach was made ventrally, just lateral to the lower spine, and the sympathetic supply dissected out. Of the animals surviving operation, one-third proved to have incomplete denervation and are not included in this series. Successful operations produced a complete flail left hind limb, showing obvious muscle atrophy from the hip level downwards.

\section{Administration of Isotopes and Separation of Tissues}

14 days after operation, six rabbits, selected for complete paralysis of the left hind limb, were injected subcutaneously in the upper abdomen with $10 \mu \mathrm{c} . \alpha^{-14} \mathrm{C}$ glycine per $100 \mathrm{~g}$. body weight, and $200 \mu$ c. $\mathrm{Na}_{2}{ }^{35} \mathrm{SO}_{4}$ per 100 g. body weight. The rabbits were then killed serially from 10 hours after isotope injection to 4 days afterwards.

The skin was stripped from both hind limbs down to the toes, which were cut off. The limbs were cut through and dislocated at the level of the femoral head. All muscle and associated fascia from each limb was removed, and this constituted the soft tissue compartment. The tissue samples were reduced to a homogeneous powder by repeated freezing in liquid nitrogen and pounding in a steel mill. After removal of aliquots for determination of total constituents the tissue fractions were separated as follows:

Collagen Fractions. - Neutral salt-soluble collagen, acidic citrate-soluble, and insoluble collagens were separated and purified, essentially as described by Jackson (1957).

The collagen content of the separated fractions was estimated by the method for hydroxyproline given below.

Sulphated Polysaccharide.-All material remaining, including supernatants, from each stage of collagen fractionation was treated as described in other experiments (Slack, 1958). The method has been shown to give good recovery of sulphated polysaccharide free from protein or hyaluronic acid (Scott, 1955). As isolated, the polysaccharides are therefore those soluble in neutral salt, acid citrate buffer, and $0 \cdot 1 \mathrm{~N} \mathrm{NaOH}$, free or associated with tissue protein in the natural state. The associated protein was hydrolysed by treatment with papain to facilitate its removal.
Separated polysaccharide was estimated gravimetrically. Chemical analyses of the acetone driects. preparations were done, to determine sulphate and: hexosamine contents, as described below.

\section{Chemical Analyses}

Hydroxyproline.-Estimated by the Neuman anc Logan method as modified by Miyada and TappeP (1956).

Hexosamine.-Determined by the method of Boas (1953).

Sulphate.-Estimated according to the methoo described in a previous communication (Slack, 1958) $\bar{\alpha}$

\section{Radioactivity Measurements}

Collagen.-Preparation and isolation of $2: \overrightarrow{4}$ dinitro-phenylglycine was as described by Neuberger Perrone, and Slack (1951). Radioactivities were determined on solid samples of "negligible thicke ness" according to the method of Henriques Henriques, and Neuberger (1955), or on solid samples of "infinite thickness" when quantities inf excess of $25 \mathrm{mg}$. crystalline DNP-glycine weré available.

Sulphate.-This was separated as the 4-chloro-4' amino diphenyl derivative and radioactivities were determined as previously described (Slack, 1958).

\section{Results}

2 weeks after neurectomy total wasting in the atrophying left limb amounted to 23 per cent. in terms of the weight of the normal right hind limbọ The greater part of this wasting occurred in the soft tissues (Table I, opposite); 16 weeks after opera 3 tion loss of tissue in the atrophying limb amounte to 44 per cent., but at 19 weeks it had increased only to 47 per cent. These figures are similar to the rates of total tissue wasting found in the rat (Slack? 1954).

The amounts of collagen fractions obtained are shown in Table II (opposite). As expected, the greater part of the collagen was in the insoluble phase. Neutral salt-soluble collagen formed onl $\mathbb{R}$ a very small part of the total collagen. The amount $\xi^{\omega}$ obtained after final purification were so small as to present analytical difficulties. Quantitative an $\$$ radioactivity measurements on the neutral salt soluble fraction of collagen are probably therefore subject to greater experimental variation than eithef of the two remaining collagen fractions. Consis tently smaller amounts of neutral salt-soluble collagen were obtained from the atrophying limbso 
TABLE I

WET WEIGHT OF WHOLE TISSUES IN NORMAL AND ATROPHYING RABBIT LIMBS

14 DAYS AFTER NEURECTOMY AND 16 TO 19 WEEKS AFTER

(Percentage wasting expressed as percentage difference from the opposite normal limb)

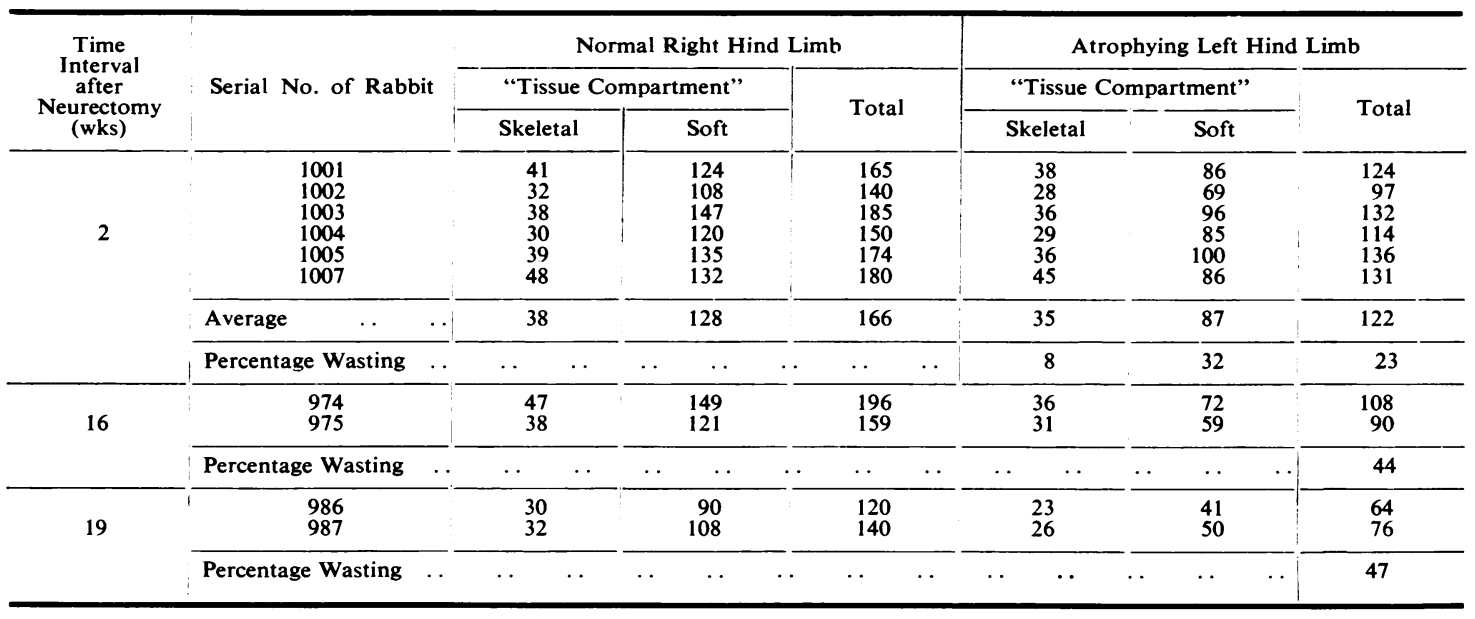

TABLE II

AMOUNTS OF COLLAGEN FRACTIONS, AND COMPARISON OF TOTAL SEPARATED FRACTIONS

WITH TOTAL COLLAGEN IN ORIGINAL MATERIAL

(Collagen contents determined by the method of Miyada and Tappel (1956))

\begin{tabular}{|c|c|c|c|c|c|c|c|c|c|c|c|c|c|}
\hline \multirow{3}{*}{$\begin{array}{l}\text { Serial No. } \\
\text { of Rabbit }\end{array}$} & \multirow{3}{*}{ Material } & \multicolumn{8}{|c|}{ Separated Collagens (g./100 g. fresh tissue) } & \multirow{2}{*}{\multicolumn{2}{|c|}{$\begin{array}{c}\text { Total } \\
\text { Collagen in } \\
\text { Original } \\
\text { Material } \\
\text { (B) }\end{array}$}} & \multirow{2}{*}{\multicolumn{2}{|c|}{$\begin{array}{c}\text { Difference } \\
\text { between } \\
A \text { and } B \\
\text { as percentage } \\
\text { of } B\end{array}$}} \\
\hline & & \multicolumn{2}{|c|}{$\begin{array}{c}\text { Neutral } \\
\text { Salt- } \\
\text { soluble }\end{array}$} & \multicolumn{2}{|c|}{$\begin{array}{l}\text { Acidic } \\
\text { Citrate- } \\
\text { soluble }\end{array}$} & \multicolumn{2}{|c|}{ Insoluble } & \multicolumn{2}{|c|}{$\begin{array}{c}\text { Total } \\
\text { (A) }\end{array}$} & & & & \\
\hline & & Skeletal & Soft & Skeletal & Soft & Skeletal & Soft & Skeletal & Soft & Skeletal & Soft & Skeletal & Soft \\
\hline 1001 & $\begin{array}{l}\text { Normal } \\
\text { Atrophying }\end{array}$ & $\begin{array}{l}0.0029 \\
0.0020\end{array}$ & $\begin{array}{l}0.0021 \\
0.0014\end{array}$ & $\begin{array}{l}1 \cdot 35 \\
1.53\end{array}$ & $\begin{array}{l}0.36 \\
0.81\end{array}$ & $\begin{array}{l}23 \cdot 2 \\
18 \cdot 7\end{array}$ & $\begin{array}{l}2 \cdot 09 \\
1 \cdot 50\end{array}$ & $\begin{array}{l}24 \cdot 5 \\
20 \cdot 2\end{array}$ & $\begin{array}{l}2 \cdot 45 \\
2 \cdot 31\end{array}$ & $\begin{array}{l}26 \cdot 9 \\
27 \cdot 5\end{array}$ & $\begin{array}{l}2.95 \\
3.61\end{array}$ & $\begin{array}{l}10 \\
26\end{array}$ & $\begin{array}{l}17 \\
36\end{array}$ \\
\hline 1002 & $\begin{array}{l}\text { Normal } \\
\text { Atrophying }\end{array}$ & $\begin{array}{l}0.0032 \\
0.0021\end{array}$ & $\begin{array}{l}0.0024 \\
0.0012\end{array}$ & $\begin{array}{l}1 \cdot 05 \\
1 \cdot 23\end{array}$ & $\begin{array}{l}0.39 \\
0.56 \\
\end{array}$ & $\begin{array}{l}22 \cdot 1 \\
19 \cdot 5\end{array}$ & $\begin{array}{l}3 \cdot 36 \\
2 \cdot 29\end{array}$ & $\begin{array}{l}23 \cdot 1 \\
20 \cdot 8\end{array}$ & $\begin{array}{l}3 \cdot 75 \\
2 \cdot 85\end{array}$ & $\begin{array}{l}26 \cdot 2 \\
27 \cdot 0\end{array}$ & $\begin{array}{l}4 \cdot 41 \\
4 \cdot 80\end{array}$ & $\begin{array}{l}12 \\
23\end{array}$ & $\begin{array}{l}15 \\
40\end{array}$ \\
\hline 1003 and 1004 & $\begin{array}{l}\text { Normal } \\
\text { Atrophying }\end{array}$ & $\begin{array}{l}0.0021 \\
0.0018\end{array}$ & $\begin{array}{l}0.0022 \\
0.0010\end{array}$ & $\begin{array}{l}1 \cdot 14 \\
1 \cdot 35\end{array}$ & $\begin{array}{l}0.32 \\
0.54\end{array}$ & $\begin{array}{l}22 \cdot 6 \\
20 \cdot 6\end{array}$ & $\begin{array}{l}1.87 \\
1.61\end{array}$ & $\begin{array}{l}23 \cdot 8 \\
21 \cdot 9\end{array}$ & $\begin{array}{l}2 \cdot 19 \\
2 \cdot 15\end{array}$ & $\begin{array}{l}26 \cdot 4 \\
27 \cdot 9\end{array}$ & $\begin{array}{l}2 \cdot 72 \\
3 \cdot 38\end{array}$ & $\begin{array}{l}10 \\
21\end{array}$ & $\begin{array}{l}20 \\
36\end{array}$ \\
\hline 1005 and 1007 & $\begin{array}{l}\text { Normal } \\
\text { Atrophying }\end{array}$ & $\begin{array}{l}0.0027 \\
0.0017\end{array}$ & $\begin{array}{l}0.0020 \\
0.0013\end{array}$ & $\begin{array}{l}1 \cdot 22 \\
1.68\end{array}$ & $\begin{array}{l}0.31 \\
0.60\end{array}$ & $\begin{array}{l}23 \cdot 1 \\
19 \cdot 9\end{array}$ & $\begin{array}{l}3.00 \\
1.57\end{array}$ & $\begin{array}{l}24 \cdot 3 \\
21 \cdot 6\end{array}$ & $\begin{array}{l}3 \cdot 00 \\
2 \cdot 16\end{array}$ & $\begin{array}{l}27 \cdot 4 \\
28 \cdot 5\end{array}$ & $\begin{array}{l}3 \cdot 70 \\
4 \cdot 06\end{array}$ & $\begin{array}{l}13 \\
25\end{array}$ & $\begin{array}{l}23 \\
46\end{array}$ \\
\hline
\end{tabular}

By contrast, larger amounts of acid citrate-soluble collagen were obtained from both skeletal and soft tissue compartments of the atrophying limbs. The insoluble collagen requires special attention.

Insoluble collagen, separated from fresh tissues as described, was found to be smaller in amount per unit weight atrophying limb as compared with the opposite normal limb. On the other hand, total collagen estimated by hydroxyproline was higher per unit weight of tissue in the atrophying limb (Table III, overleaf). The hydroxyproline figures agree with previous experience (Harkness, 1957; Slack, 1954), and it is therefore probable that the extraction procedures used have resulted in a greater loss of purified collagen in the case of atrophying tissue. Reference to the final column of Table III shows that some 15 per cent. of the initial total collagen was lost by the extraction procedure on normal tissues. In atrophying tissue at least 25 per cent. was lost. In general, the atrophying soft tissue showed a greater loss than the skeletal tissue. Some of the difference between estimated total collagen and collagen fractions separated and isolated in the atrophying limbs can be accounted for by increased acid citrate-soluble fraction. But the greater part of the collagen lost 
TABLE III

AMOUNTS OF SULPHATED POLYSACCHARIDES RECOVERED FROM SKELETAL AND SOFT TISSUES OF NORMAL AND ATROPHYING HIND LIMBS OF RABBITS 14 DAYS AFTER NEURECTOMY

(Amounts determined gravimetrically on acetone-dried specimens)

\begin{tabular}{|c|c|c|c|c|c|c|c|c|c|}
\hline \multirow{3}{*}{$\begin{array}{l}\text { Serial No. } \\
\text { of Rabbit }\end{array}$} & \multirow{3}{*}{ Material } & \multicolumn{6}{|c|}{ Sulphated Polysaccharides* (mg./100 g. fresh tissue) } & \multirow{2}{*}{\multicolumn{2}{|c|}{$\begin{array}{l}\text { Total Separated } \\
\text { Polysaccharide }\end{array}$}} \\
\hline & & \multicolumn{2}{|c|}{$\begin{array}{c}\text { Neutral Salt } \\
\text { Extract }\end{array}$} & \multicolumn{2}{|c|}{$\begin{array}{c}\text { Acidic Citrate } \\
\text { Extract }\end{array}$} & \multicolumn{2}{|c|}{$0 \cdot 1 \underset{\text { Extract }}{\mathrm{N}} \mathrm{NaOH}$} & & \\
\hline & & Skeletal & Soft & Skeletal & Soft & Skeletal & Soft & Skeletal & Soft \\
\hline 1001 & $\begin{array}{l}\text { Normal } \\
\text { Atrophying }\end{array}$ & $\begin{array}{l}19 \\
14\end{array}$ & $\begin{array}{l}12 \\
19\end{array}$ & $\begin{array}{l}6 \\
4\end{array}$ & $\begin{array}{l}4 \\
9\end{array}$ & $\begin{array}{r}108 \\
80\end{array}$ & $\begin{array}{l}33 \\
23\end{array}$ & $\begin{array}{r}133 \\
98\end{array}$ & $\begin{array}{l}49 \\
51\end{array}$ \\
\hline 1002 & $\begin{array}{l}\text { Normal } \\
\text { Atrophying }\end{array}$ & $\begin{array}{l}24 \\
16\end{array}$ & $\begin{array}{l}19 \\
18\end{array}$ & $\begin{array}{l}14 \\
10\end{array}$ & $\begin{array}{l}10 \\
11\end{array}$ & $\begin{array}{l}126 \\
112\end{array}$ & $\begin{array}{l}40 \\
32\end{array}$ & $\begin{array}{l}164 \\
138\end{array}$ & $\begin{array}{l}69 \\
61\end{array}$ \\
\hline 1003 and 1004 & $\begin{array}{l}\text { Normal } \\
\text { Atrophying }\end{array}$ & $\begin{array}{l}22 \\
19\end{array}$ & $\begin{array}{l}11 \\
16\end{array}$ & $\begin{array}{l}12 \\
18\end{array}$ & $\begin{array}{l}7 \\
3\end{array}$ & $\begin{array}{r}110 \\
66\end{array}$ & $\begin{array}{l}42 \\
36\end{array}$ & $\begin{array}{l}144 \\
103\end{array}$ & $\begin{array}{l}60 \\
55\end{array}$ \\
\hline 1005 and 1007 & $\begin{array}{l}\text { Normal } \\
\text { Atrophying }\end{array}$ & $\begin{array}{r}16 \\
7\end{array}$ & $\begin{array}{r}7 \\
15\end{array}$ & $\begin{array}{r}13 \\
8\end{array}$ & $\begin{array}{l}5 \\
7\end{array}$ & $\begin{array}{l}94 \\
79\end{array}$ & $\begin{array}{l}38 \\
22\end{array}$ & $\begin{array}{r}123 \\
94\end{array}$ & $\begin{array}{l}50 \\
44\end{array}$ \\
\hline
\end{tabular}

* Analyses of separated polysaccharides gave figures for sulphate content varying from $10 \cdot 2$ to $12 \cdot 9 \mathrm{~g} \cdot / 100 \mathrm{~g}$. polysaccharide, and of hexosamine $24 \cdot 2$ to $33 \cdot 6 \mathrm{~g} . / 100 \mathrm{~g}$. polysaccharide.

in the extraction procedure seems to result from altered stability of insoluble collagen at the stage of $0 \cdot 1 \mathrm{~N} \mathrm{NaOH}$ extraction.

The amounts of sulphated polysaccharide recovered from the tissues are shown in Table III. In most cases there was a decrease in polysaccharide in the atrophying tissues, both as recovered fractions of polysaccharide and as measured by total hexosamine. There was, however, considerable variation in the actual amounts of polysaccharide recovered per unit weight fresh tissue in normal and atrophying limbs. The variations were such as to permit only a general statement that atrophying tissue, both skeletal and soft, shows some reduction of total polysaccharide per unit weight of fresh tissue.

The data obtained on the metabolism of collagen are given in Table IV. These are admittedly scanty. From the available figures it would appear that the greater reduction of synthesis of collagen occurred in the neutral salt-soluble fraction. The synthes of this precursor fraction was reduced in both skel tal and soft tissue. At 14 days after neurectomy the greatest reduction in new synthesis of precursor cole lagen was evidenced in the soft tissues (Fig. 1, opper site). But, despite this reduction in synthesis of ne collagen, all the neutral salt fractions of collagep from the atrophying tissues showed some eviden 8 of continuing synthesis of collagen.

From Table IV it is also evident that some newle synthesized collagen becomes incorporated in bo the insoluble collagen fraction and the acid citratesoluble fractions. The figures do not permit of further evaluation beyond the fact that some incorporation of new glycine is being achieved these collagen fractions, even during active atroply of the limb tissues.

TABLE IV

SPECIFIC RADIOACTIVITIES OF COLLAGEN FRACTIONS FROM SKELETAL AND SOFT TISSUES OF NORMAL AND ATROPHYING HIND LIMBS OF RABBITS 14 DAYS AFTER NEURECTOMY

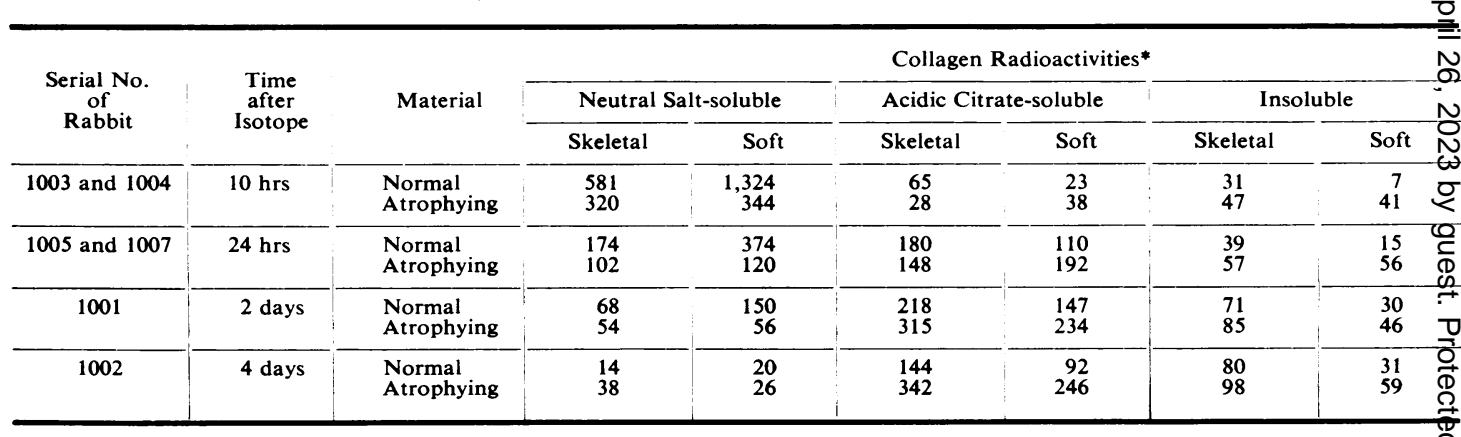

* Counts derived from $\alpha^{14} \mathrm{C}$ labelled glycine and radioactivity expressed as count $/ \mathrm{min}$. $/ \mathrm{mg}$. collagen. 


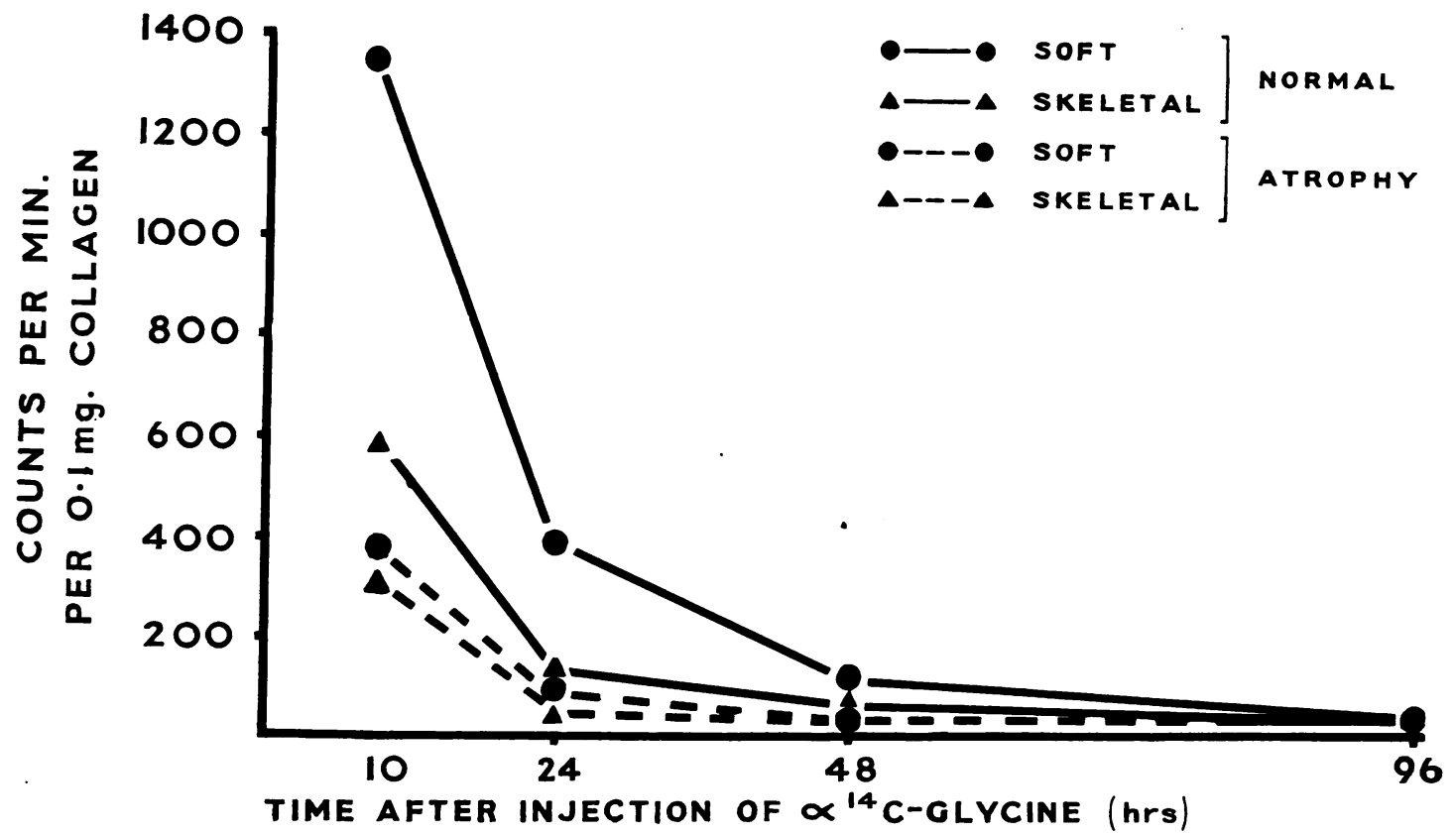

Fig. 1.-Specific activities of $\alpha^{14} \mathrm{C}$-DNP glycine in neutral salt-soluble collagen from skeletal and soft tissues of atrophying left hind limbs, and normal right hind limbs, of rabbits, 14 days after operation.

The amounts of sulphated polysaccharide recovered from the tissues are shown in Table III and their specific activities in Table V. The quantities shown in Table III are acetone dried weights of separated polysaccharides. A series of total hexosamine estimations were done on aliquots of original material. These indicated that the amounts of polysaccharide actually obtained in a relatively pure state were of the order of only one-tenth of that presumably present on the basis of total hexosamine estimation. By no means all the hexosamine in total tissue samples derives from mucopolysaccharide, but the polysaccharide actually recovered from the tissues may well be only a portion of that bound to connective tissue proteins in the living tissue.

The polysaccharide extracted from the tissues by neutral salt was small in relation to the total extracted polysaccharide, but showed relatively high specific activity in both normal and atrophying

TABLE V

SPECIFIC RADIOACTIVITIES OF POLYSACCHARIDE SULPHATE IN THREE EXTRACTS OF SKELETAL AND SOFT TISSUES OF NORMAL AND ATROPHYING HIND LIMBS OF RABBITS 14 DAYS AFTER NEURECTOMY

\begin{tabular}{|c|c|c|c|c|c|c|c|c|}
\hline \multirow{3}{*}{$\begin{array}{c}\text { Serial No. } \\
\text { of } \\
\text { Rabbit }\end{array}$} & \multirow{3}{*}{$\begin{array}{c}\text { Time } \\
\text { after } \\
\text { Isotope }\end{array}$} & \multirow{3}{*}{ Material } & \multicolumn{6}{|c|}{ Radioactivities* } \\
\hline & & & \multicolumn{2}{|c|}{ Neutral Salt Extract } & \multicolumn{2}{|c|}{ Acidic Citrate Extract } & \multicolumn{2}{|c|}{$0.1 \mathrm{~N} \mathrm{NaOH}$ Extract } \\
\hline & & & Skeletal & Soft & Skeletal & Soft & Skeletal & Soft \\
\hline 1003 and 1004 & $10 \mathrm{hrs}$ & $\begin{array}{l}\text { Normal } \\
\text { Atrophying }\end{array}$ & $\begin{array}{l}686 \\
525\end{array}$ & $\begin{array}{l}774 \\
470\end{array}$ & $\begin{array}{r}9 \\
12\end{array}$ & $\begin{array}{r}6 \\
12\end{array}$ & $\begin{array}{l}190 \\
266\end{array}$ & $\begin{array}{r}25 \\
9\end{array}$ \\
\hline 1005 and 1007 & 24 hrs & $\begin{array}{l}\text { Normal } \\
\text { Atrophying }\end{array}$ & $\begin{array}{l}620 \\
585\end{array}$ & $\begin{array}{l}542 \\
481\end{array}$ & $\begin{array}{l}22 \\
40\end{array}$ & $\begin{array}{l}12 \\
32\end{array}$ & $\begin{array}{l}461 \\
310\end{array}$ & $\begin{array}{r}272 \\
39\end{array}$ \\
\hline 1001 & 2 days & $\begin{array}{l}\text { Normal } \\
\text { Atrophying }\end{array}$ & $\begin{array}{l}505 \\
551\end{array}$ & $\begin{array}{l}409 \\
462\end{array}$ & $\begin{array}{l}37 \\
28\end{array}$ & $\begin{array}{l}10 \\
20\end{array}$ & $\begin{array}{l}342 \\
280\end{array}$ & $\begin{array}{r}119 \\
90\end{array}$ \\
\hline 1002 & 4 days & $\begin{array}{l}\text { Normal } \\
\text { Atrophying }\end{array}$ & $\begin{array}{l}200 \\
307\end{array}$ & $\begin{array}{l}237 \\
351\end{array}$ & $\begin{array}{l}22 \\
36\end{array}$ & $\begin{array}{r}5 \\
24\end{array}$ & $\begin{array}{l}206 \\
249\end{array}$ & $\begin{array}{r}33 \\
110\end{array}$ \\
\hline
\end{tabular}

* Radioactivity expressed as count $/ \mathrm{min} . / 0 \cdot 1 \mathrm{mg}$. sulphate. 
limbs. There was no unequivocal evidence of a marked reduction of metabolic activity in this fraction from the atrophying limbs. But how much of this polysaccharide fraction was bound to neutral salt-soluble collagen, and how much to the tissue proteins, is at present uncertain.

The acidic citrate extract of polysaccharide appears to have similar specific activity-time relations to the alkali extract, but the specific activities were much smaller at all intervals of time.

By far the greater part of the total polysaccharide was not liberated until the final stage of extraction with $0.1 \mathrm{~N}$ alkali. This portion of the polysaccharide was that bound by insoluble connective tissue proteins. The specific activities (of this bound polysaccharide) were higher in the skeletal fractions than in the soft tissue, but in all cases much less than the specific activity found in the neutral salt-extractable polysaccharide. The figures suggest a lower rate of turnover of this polysaccharide fraction from the soft tissues in the atrophying limb, and some reduction in specific activity in the skeletal compartment (Fig. 2).

\section{Discussion}

From the limited evidence of these experiments and from previous work (Slack, 1954), it seems clear that massive tissue atrophy does not imply a complete cessation of connective tissue synthesis. đ্s might be expected, there does seem to be a reduction of synthesis of both collagen and polysaccharide both skeletal and soft tissues of the atrophying lim

This reduced synthesis is most evident in the sift tissues at 14 days of atrophy. Since the soft tissues are atrophying at a much greater rate than the skeletal compartment this finding is not surprisings. In the case of collagen, the greatest reduction of synthesis occurs in the neutral, salt-soluble, precursor collagen of the atrophying limb. Both the acidic citrate-soluble and insoluble collagens a $\$ 0$ show some evidence of a reduced rate of metabojic turnover.

It is regrettable that insufficient polysaccharifle could be isolated from the precursor collagen fraction to permit adequate analysis. There does appear, however, to be a marked difference $q_{n}$ metabolic behaviour between the main polysaccharide $(0 \cdot 1 \mathrm{~N}$ alkali) fractions from skelefe्cl and soft tissues. In the skeletal tissue the main bu像k of polysaccharide from the atrophying limb shoys evidence of continuing synthesis in substantigl amounts. On the other hand, that from the soft tissues of the atrophying limb shows definde evidence of a slowing down of synthesis.

From these and earlier experiments in the

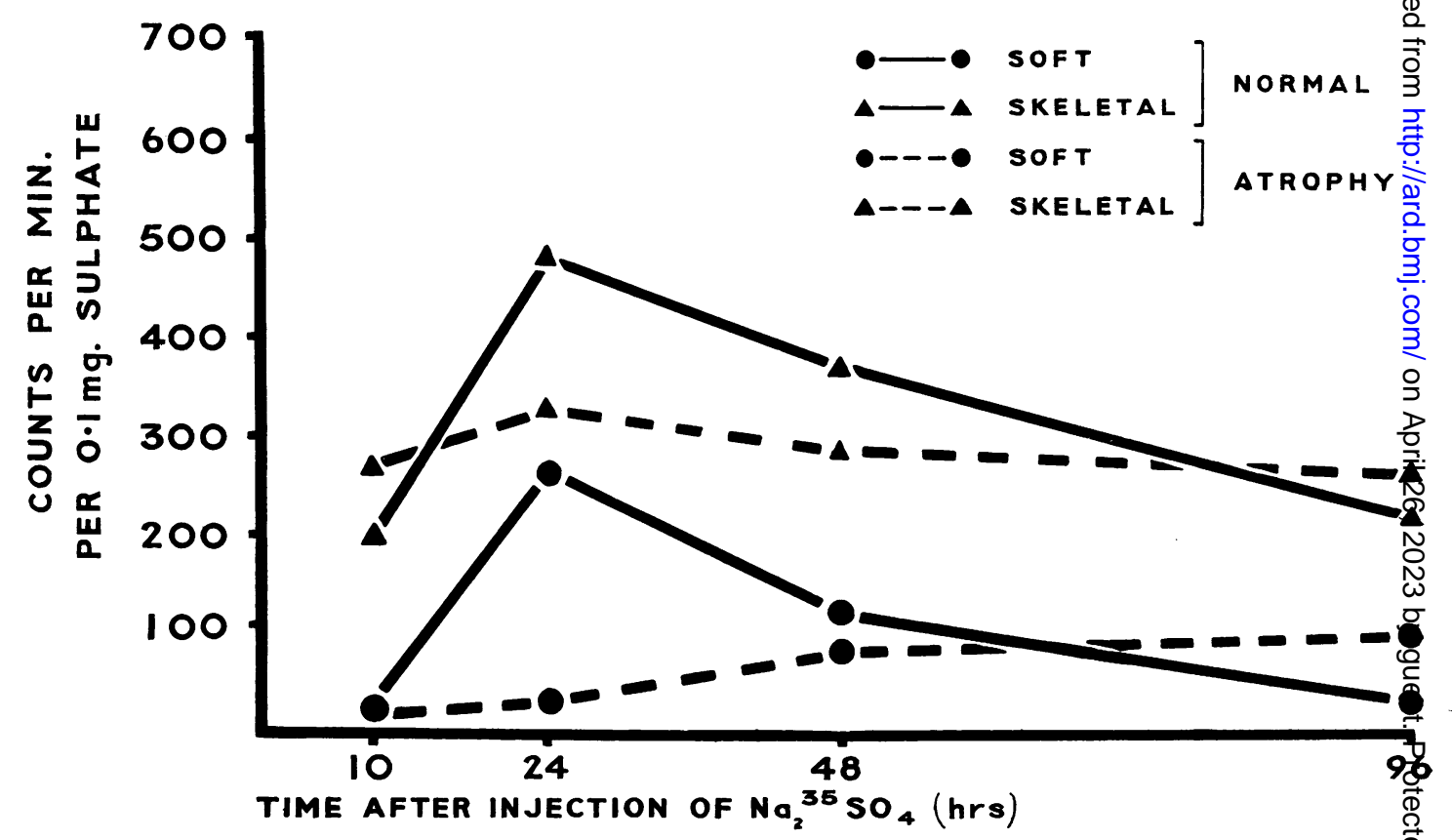

Fig. 2.-Specific activities of ${ }^{35} \mathrm{SO}_{4}$ in polysaccharide extracted by $0 \cdot 1 \mathrm{~N} \mathrm{NaOH}$ from skeletal and soft tissues of atrophying left hind linß and normal right hind limbs, of rabbits, 14 days after operation. 
(Slack, 1954), and from the work of Gillespie (1954), Geiser and Trueta (1958), and others, it seems clear that massive tissue atrophy is a metabolically active process. It would seem to be an energy-requiring process. Therefore, a continued blood supply, and some continuing synthesis of new connective tissue components would appear, ordinarily, to be an essential requirement.

\section{Summary}

(1) Massive tissue atrophy was achieved in the left hind limb of six rabbits by extensive neurectomy and sympathectomy.

(2) 14 days after operation, $\alpha^{14} \mathrm{C}$-glycine and ${ }^{35} \mathrm{~S}$ labelled sodium sulphate were injected subcutaneously, and the animals were killed at $10 \mathrm{hrs}, 24 \mathrm{hrs}$, 2 days, and 4 days afterwards.

(3) From the atrophying limb and opposite normal limb in each case, the tissues were separated into a soft tissue compartment (muscle, fascia, and tendon) and a skeletal compartment (bones, joints, and tendon insertions).

(4) Collagen was separated in three fractions: neutral salt-soluble precursor collagen, acidic citrate-soluble collagen, and insoluble collagen. Sulphated polysaccharide was separated in three similar fractions.

(5) In the case of collagen, there is evidence of continued synthesis in both skeletal and soft tissues of the atrophying limbs. The most marked reductions in metabolic activity were found in the soft tissue compartment (which is atrophying most rapidly), and particularly in the neutral salt-soluble collagen.

(6) The main portion of the sulphated polysaccharide, the final alkali-soluble fraction, also shows some reduced metabolic activity, most marked in the soft tissues. The behaviour of polysaccharide associated with the precursor collagen could not be assessed.

(7) The findings provide additional evidence that, although synthesis of collagen and polysaccharide is almost certainly reduced in massive tissue atrophy, there is no complete cessation of these processes.

We wish to thank Prof. J. H. Kellgren for many suggestions and continued encouragement, and Miss K. Broady and Mr. D. Myhill for their technical assistance.

\section{REFERENCES}

Boas, N. F. (1953). J. biol. Chem., 204, 553.

Geiser, M. and Trueta, J. (1958). J. Bone Jt Surg., 40B, 282.

Gillespie, J. A. (1954). Ibid., 36B, 464.

Harkness, R. D. (1957). "Metabolism of Collagen," in "Lectures on the Scientific Basis of Medicine," vol. 5, 1955-56, p. 183. British Postgraduate Medical Federation. Athlone Press, London.

Helander, E. (1957). Acta physiol. scand., 41, Suppl. 141
Henriques, O. B., Henriques, S. B., and Neuberger, A. (1955). Biochem. J., 60, 409

Jackson, D. S. (1957). Ibid., 65, 277

Miyada, D. S., and Tappel, A. L. (1956). Anal. Chem., 28, 909

Neuberger, A., Perrone, J. C., and Slack, H. G. B. (1951). Biochem. J., 49, 199.

Scott, J. E. (1955). Biochim. biophys. Acta, 18, 428.

Slack, H. G. B. (1954). Clin. Sci., 13, 155 .

Slack, (1955). Biochem, J.60, 112.

(1958). Ibid., 69, 125 .

Métabolisme du tissu conjonctif dans l'extrémité atrophiée du lapin

RÉSUMÉ

(1) On provoqua une atrophie massive des tissus de la patte postérieure gauche de six lapins par des neurectomies et sympathectomies étendues.

(2) Quatorze jours après l'opération, on injecta par voie souscutanée les radio-isotopes ${ }^{14} \mathrm{C}$-glycine et ${ }^{35} \mathrm{~S}$ sulfate de soude et on sacrifia les animaux 10 heures, 24 heures, 2 jours et 4 jours plus tard.

(3) Dans tous les cas les tissus de la patte atrophiée et de la patte correspondante normale furent divisés en partie molle (muscle, fascia et tendon) et squélettique (os, articulation et insertion tendineuse).

(4) Le collagène fut divisé en trois portions: collagène précurseur, soluble en présence de sel neutre, collagène soluble en présence de citrate acide et collagène insoluble. Le polysaccharide sulfaté fut divisé en trois portions similaires.

(5) En ce qui concerne le collagène, on trouva des indices que sa synthèse continue aussi bien dans le tissu squélettique que mou des extrémités atrophiées. L'activité métabolique la plus réduite fut constatée dans la partie comprenant du tissu mou (qui s'atrophie le plus rapidement), et particulièrement dans le collagène soluble en présence de sel neutre.

(6) La portion principale du polysaccharide sulfaté, celle qui se dissout finalement dans l'alcali, accusa aussi une réduction de l'activité métabolique, plus marquée dans les tissus mous. On ne put pas déterminer le comportement du polysaccharide associé au collagène précurseur.

(7) Ces résultats offrent des preuves additionnelles montrant que, bien que la synthèse de collagène et de polysaccharide soit presque certainement réduite dans une atrophie massive des tissus, elle ne cesse pas entièrement.

\section{Metabolismo del tejido conjuntivo en la extremidad atrofiada del conejo}

SUMARIO

(1) Se produjo una atrofia masiva de los tejidos de la pata trasera izquierda de seis conejos por neurectomias y simpatectomias extensas.

(2) Catorce días después de la operación se inyectaron por vía subcutánea los radio-isótopos ${ }^{14} \mathrm{C}$-glicina y ${ }^{35} \mathrm{~S}$ sulfato de sodio y los animales fueron sacrificados 10 horas, 24 horas, 2 días y 4 días después.

(3) En todos los casos los tejidos de la pata atrofiada y de la pata correspondiente normal fueron divididos en dos partes: una blanda (músculo, fascia y tendón) y la otra esquelética (hueso, articulación e inserción tendinosa).

(4) El colágeno fué dividido en tres porciones: colágeno precursor, soluble en presencia de sal neutra, colágeno soluble en presencia de citrato ácido y colágeno insoluble. El polisacarido sulfatado fué dividido en tres porciones similares.

(5) En el caso de colágeno, encontráronse indicios 
de que su sintesis continua tanto en el tejido esquelético como en el blando de las patas atrofiadas. La mayor reducción de la actividad metabólica fué encontrada en el tejido blando (que se atrofía más rápidamente), particularmente en el colágeno soluble en presencia de sal neutra.

(6) La porción principal del polisacarido sulfatado, aquella que se disolve finalmente en el álcali, también acusó una reducción de la actividad metabólica, más pronunciada en los tejidos blandos. No se pudo detef minar el comportamiento del polisacarido asociado क्ष़ colágeno precursor.

(7) Estos resultados ofrecen datos adicionales mo trando que, aunque la síntesis del colágeno y del polit sacarido se vea casi ciertamente reducida en una atrofa masiva de los tejidos, este proceso no cesa enteramente. 